\title{
Race in The Bahamas: A Dysfunctional Narrative
}

\author{
Keith A. Russell \\ The College of The Bahamas ${ }^{1}$
}

\begin{abstract}
This essay addresses the ways in which the conversation about race in The Bahamas is predicated upon avoidance, obfuscation, and incoherence. Further, it critiques some traditional and sacred narratives concerning the protracted problems of race in the Bahamian archipelago. Then, briefly, it examines the historical circumstances which gave rise to the present paralysis, and offers suggestions on how to move forward towards "one Bahamas", thus overcoming the obvious racial divide, and simultaneously, healing some old wounds too long left to fester.
\end{abstract}

\section{INTRODUCTION}

It is now accepted, in most quarters, that the transatlantic slave trade was motivated by economics, and that race and racism became the ideological underpinnings that buttressed this diabolical system. Consequently, not only did slavery provide free labour for the cotton fields of the American South, the houses and factories of the American North, and the sugar plantations of the Caribbean, but it enlisted and encouraged a cadre of pseudo-scientists and quasi-intellectuals to rewrite history, distort facts and poison the public discourse where people of African descent were concerned. The science of eugenics thrived in this putrid environment.

One of the first important individuals to propagate the nonsense of African inferiority was one of the drafters of the Declaration of Independence for the United States of America, Thomas Jefferson. In his Notes on the State of Virginia (1997), in the section called "Laws" he writes, "I advance it therefore as a suspicion only, that the blacks,
... are inferior to the whites in the endowments both of body and mind. ... This unfortunate difference of colour, and perhaps of faculty, is a powerful obstacle to the emancipation of these people" (pp.102-103). It was perhaps these early Jeffersonian comments, according to Farrow, Lang, and Frank (2005), which emboldened persons like Samuel George Morton, Josiah Nott and Louis Agassiz. The latter two men's 700page paean to Morton, which concluded that Blacks were not even of the same species as Whites, was a companion piece, in the pantheon of idiocy, to Morton's assessment that Blacks were doomed to inferiority based on the smallness of their cranial capacity. Even Dr. Benjamin Rush, also a signer of the Declaration of Independence and an abolitionist, believed blackness to be a malady. Citing the supposed whitening of a Black man, Henry Moss, Rush believed that one day a cure might be found for blackness (Farrow, Lang \& Frank, 2005, pp. 179-191).

Unfortunately, these virulent ideas, like

\footnotetext{
${ }^{1}$ Keith A. Russell, Adjunct Professor of English and Theology, School of English Studies, The College of The Bahamas, Northern Bahamas Campus, P.O. Box F-41630, Freeport, Grand Bahama, Bahamas.

E-mail: drkeithrussell@hotmail.com

How to cite this article in APA style (7th ed.): Russell, K. (2009). Race in The Bahamas: A dysfunctional narrative. The College of The Bahamas Research Journal, 15; 1-7. https://doi.org/10.15362/ijbs.v15i0.107
} 
airborne viruses, learned the art of travel. They jumped off ships stopping in the Caribbean after their murderous trek across the Middle Passage, they were shipmates with the Eleutheran Adventurers and the Loyalists, and they scurried ashore with the protracted travel of privileged Whites between The Bahamas and the United States, and between The Bahamas and Europe. And like prickly running vines, they pushed themselves into the pristine soil and permeated every parcel of our primitive landscape. After all, "it's better in The Bahamas". They have been with us for almost four hundred years. And our demographics in this sun-kissed archipelago, along with our social conduct, are indications that they are still here. They may have mutated somewhat with time, but are no less dangerous.

However, in The Bahamas we pretend that these malignant ideas are extinct, and, therefore, can no longer influence behaviour. Felix Moss (2005) in a candid piece in The Tribune points out that our Bahamaland is “...very much a race-driven colour conscious society" (p. 4). He cites the absence of White Bahamians working in the civil service, as straw vendors and as hotel workers; yet these same civil servants, straw vendors and hotel workers spend their money for goods and services in commercial establishments owned by White Bahamians. Moss cites this as evidence that rancid ideas about race are still operative among us. He concludes that White Bahamians “... want economic inclusion but practice social apartheid” (p. 4).

Nicolette Bethel (2007), in an insightful commentary in the The Nassau Guardian, outlines the objections some Bahamians have towards race as a part of public discourse: "Slavery is over, and everybody's now equal. Crying victimhood does nobody any good, and casting blame doesn't help either" is offered as the first objection; the second is that "Slavery has always existed ... It doesn't do much good to focus solely on one kind ... Africans themselves kept slaves, and even sold those slaves to Europeans” (p. L2).

Unquestionably, the dysfunction of our national narrative on race is precipitated by our reluctance to engage in critical analysis and our refusal to have a public conversation regarding those matters delineated by Moss and Bethel. We brag about, celebrate, and wear as a national badge of honour our 'quiet revolution'. This word, 'quiet', seared into our national consciousness, is symptomatic of narrative dysfunction-our disinclination to confront the unflinching truth about our story, and how it influences the present and threatens the future. "True true stories are rebels," writes Helen Klonaris (2006) in "On Whiteness and Being Bahamian", one of the most honest, insightful and thought-provoking pieces on race in The Bahamas. She goes on to say, "They (stories) have the power to liberate people. From our lies. Even when we are afraid” (p. 4).

The poet C.K. Williams coined the phrase "narrative dysfunction" to outline the process by which we lose track of the story of ourselves, the story that tells us who we are. Charles Baxter (1994) writes: "Every story is a history, however, and when there is no comprehensible story, there is, in some sense, no history; the past, under those circumstances, becomes an unreadable mess" ( 9 ). He offers that: "One of the signs of a dysfunctional narrative is that we cannot leave it behind, and we cannot put it to rest, because it does not, finally, give us the explanation we need to enclose it” (ף 10). Listen to most public conversation about race in this country and you will realize that our story is incoherent, dismembered. Ours is a tragic psychic landscape of paralysis brought on by an intense fear of truth-telling, or a calculated avoidance of truth. Our racial harmony has been stymied by this conspiracy of silence. 


\section{COUNTERING \& EXPOSING DYSFUNCTION}

Was our revolution 'quiet'-really? Is quiet still being defined as the lack of bloodshed in the dubious achievements of independence and Majority Rule? Are there still persons in the post-modern Bahamas who believe that either of these accomplishments was wrought without blood? Undoubtedly, the lingering presence of this idea is a testimony to narrative dysfunction. The fight for independence began on the day the first European arrived in Africa, threw his net over the first African body, and yanked her from the soil of her birth.

There was nothing quiet or bloodless about Africans being dragged across the Middle Passage, nothing quiet or bloodless about the rape of our African mothers, nothing quiet or bloodless about being sold into chattel slavery. Moreover, there was nothing quiet or bloodless about being denied public access and accommodations in the country of our birth-in accommodations whose paint and plaster conceal the blood stains on the bricks and wooden planks left there by the labour of our black, busted hands; there is nothing quiet or bloodless about persons seeking secession from The Bahamas-who did resort to violence-because Black rule was one thing, but black independent rule-without White power to oversee from afar-was inconceivable; nothing quiet or bloodless about a social system predicated upon race where the accumulated atrocities visited upon Bahamians of African descent are still wailing to be told. To paraphrase an African proverb, "until the lion learns to write, the narrative of the hunt will always be dysfunctional, skewed in favour of the hunter". The stories of the hunted wounded, deprived, murdered lion in this peculiar jungle are not in our songs, barely in our literature and visual arts, and perpetually absent from our public discourse.

And when we do talk, the narrative is usually incomprehensible. A purported interview of Michael Lightbourn on a Love 97 radio talk show, Jones and Company, illustrates the point. "The $\mathrm{UBP}^{2 \text { ", }}$, he says, "had a bad connotation $\ldots$ because of what the $\mathrm{PLP}^{3}$ said about it. ... The UBP was not responsible for what happened (to Black Bahamians) at hotels (in The Bahamas)” (Gay, 2006).

Recently, some overtures have been made by former British Prime Minister Tony Blair and the United Nations concerning transatlantic slavery. Some may call them apologies. They seemed more like acknowledgements. However, nothing can detract from their absurdity. Still, it is difficult to have such a discussion in the midst of narrative dysfunction. In order for the narrative to be comprehensible someone has to take responsibility for the brutality. The UBP had a "bad connotation". No, the party can't be defined as or accused of being engaged in any gross human rights violation, of inflicting any physical or psychological pain; it is just that the atmosphere surrounding it made it appear to be wicked. And most of this "connotation" was certainly not because of any viciousness on the part of the UBP; no, this connotation was the result of what the PLP said about the UBP.

Amazingly, dysfunctional narratives ignore history. The UBP was made up of the White elite, rich merchants who owned businesses on Bay Street in the capital, Nassau. They were given the popular name the "Bay Street Boys”. This right-of-center group controlled the affairs of The Bahamas long before it became a political party. Many of its members were racist and their policies were self-serving and oppressive to the majority of the population who were Black. The atmosphere of discrimination that they weaved into the social fabric of the nation based on colour was well entrenched for over

\footnotetext{
${ }^{2}$ United Bahamian Party (UBP) formed in 1958.

${ }^{3}$ Progressive Liberal Party (PLP) formed in 1953.
} 
half a century before the left-of-center PLP emerged on the political landscape. The PLP's aim was to free Blacks from the oppressive régime of the Bay Street Boys, who collectively formed the UBP, and create a more equitable society. Any attempts to claim that the UBP was not sinister and that any such evaluation was merely PLP propaganda is the epitome of dysfunction.

In other rare interviews where the question of race is raised, usually a White man will point out how a White businessman helped a particular Black person or persons to get some of the crumbs of our economic pie. This is true-very much a part of our history. What make such narratives dysfunctional is that they are not the whole truth. These renderings are employed in defence of an iniquitous system, trying to make it appear benign. Certainly, any Black person being helped by a White businessman during our apartheid era was the exception rather than the rule. And more often than not, this generosity was not altruistic; rather, it was the favour that the malicious system allotted to good niggers-Black persons who knew their stations and served without complaint or protest. Obviously, deniability, evasion, and revisionism are at the heart of narrative dysfunction. Yes, our life together where race is concerned is a convoluted fiction. We are living in Dickens' Tale of Two Cities, or is that two countries; one White, one Black and a small border between where a few of us tolerate one another mostly for instrumental reasons.

The lie that is seeking permanency in these isles, which is the pulse of our dysfunction, is that nothing happened to us. We in The Bahamas, as the narrative goes, didn't suffer the harshness of those further South. The insanity implicit in this recitation is that we descendants of slaves could even allow ourselves to be engaged in a narrative about degrees of servitude. In addition, many
Bahamians believe that slavery is a thing of the past. This is why, as Bethel exclaims, many are saying that we should leave it in the past; let's cease the conversation. Of course, Amos N. Wilson (1993) convincingly concludes: "Those of us who are Afro-centric and mystical must know that the division of past, present and future is false, Eurocentric and political” (p. 20). This point is potent in a 'Christian' nation, where on Saturday and Sunday preachers wax eloquent, at times insightfully-to the jubilation of their congregations-about ancient Israel's enslavement in Egypt. This enslavement occurred thousands of years before the transatlantic slave trade, and no voices are claiming that we should discontinue conversation concerning it. The logic is elusive.

But Wilson is correct: slavery is never a thing of the past, particularly in our present circumstances. Bahamians are still dealing with the psychic damage inflicted by slavery—all Bahamians, whether or not we are conscious of it. White Bahamians, at least the ones who care about our wholeness, are wrestling with the disease of superiority and privilege, trying to get over their irrational fear and suspicion of the rest of us, so they can fully join us in our lives together. Blacks are wrestling with inferiority, trying to work through the collective pain of memory, trying to work past revenge and distrust, so we can genuinely invite our White brothers and sisters from the margins to build our lives together. We should never mistake our tolerance of one another on a pragmatic level for genuine catharsis. Nor should we allow the few visible ones, who seem to have moved farther along the road to wholeness, to dupe us into believing that they represent most of us. Because most of us, on both sides of the divide, are still very ill. In the public square, if one cares to really look, there are a thousand ways White Bahamians act out 
superiority; similarly, Black Bahamians genuflect to whiteness in a thousand subtle ways, acting out inferiority. The disease is still affecting us.

As Toni Morrison (1987) points out in her already classic arterial novel of excavation, Beloved, every house is filled with these ghosts. Spirit outlives flesh; the voices are not silent; the wounds are not closed. Our collective experience has dismembered us. How do we put ourselves back together? How do we get the blood flowing again? In a marvellous passage in the novel, the slave Sethe has escaped from the plantation Sweet Home on her way to Ohio and freedom, but her feet are swollen so badly she can't stand anymore so she is lying in the bushes. Soon, a White girl who calls herself Amy happens along. "Look there. A nigger. If that don't beat all. ... You 'bout the scariest-looking something I ever seen. What you doing back up in here?" "Running," Sethe tells her. "Them the feet you running on?" The two of them then strike up a conversation, becoming more familiar with each other, as Sethe crawls along the ground and Amy walks. After some time, Morrison offers this remarkable notation: "Then she did the magic: lifted Sethe's feet and legs and massaged them until she cried salt tears." "It's gonna hurt, now," said Amy. "Anything dead coming back to life hurts” (p. 35).

In another wonderful exchange in the novel, Beloved leaves the big house in the middle of the night and enters the shed where the exslave, and Sethe's lover, Paul D, has retreated because he feels restless and haunted in the house. In some ways, Morrison suggests that Beloved is Sethe's murdered daughter returning to this realm. As she enters the shed she begins to take off her clothes and says to Paul D: "I want you to touch me on the inside part and call me my name." He tries to persuade her to leave, but she is insistent, continuing to repeat herself. He keeps refusing. Finally, she tells him if he calls her name she will leave; he does, but she doesn't. She moves closer to him. Now earlier in a conversation with Sethe, Paul D had told her that he doesn't feel anything anymore. His heart is a tobacco tin inside his chest. All the awful memories of Sweet Home are locked away in it, and it has rusted shut. Paul D doesn't want to remember, to feel; it is too painful, too hideous. He doesn't want to go in. But recovery always requires diving into the wreck. Beloved goes closer and touches Paul D. His back is to her. Morrison writes:

She moved closer with a footfall he didn't hear and he didn't hear the whisper that the flakes of rust made either as they fell away from the seams of his tobacco tin. So when the lid gave he didn't know it. What he knew was that when he reached the inside part he was saying, 'Red heart. Red heart,' over and over again. ... 'Red heart. Red heart. Red Heart' (p. 117).

Perhaps, in The Bahamas our feet are swollen and cracked, running from each other, and although we brag about-and certainly have achieved-economic prosperity for some, the heart of this nation is locked away in a tin; we don't want to go in; we don't want to see; but if we are going to get the blood flowing, going to feel-have compassion-for each other, we will have to risk intimacy. Real intimacy. We will have to caress each other's cracked, swollen, throbbing feet. We will have to traverse that distance between the big house and the shed, no matter how dark it is outside, no matter how many strange sounds we hear, no matter how many ghosts we encounter. And when we are in the same space, we will have to turn around and face each other and talk about everything, refusing to exit until we touch. Until being together is not strange and awkward, but common. We need to articulate a narrative that is coherent, one that says something true, one that helps us to find ourselves. 


\section{CONCLUSIONS}

But how do we proceed? We must make the white house a room in our house and not the house itself, and at the same time we must be aware of Audre Lorde's (1984) admonition: "The master's tools will never dismantle the master's house" (p. 110). If we are to construct a functional narrative about race we need new tools, new symbols, and a new language. We need the tools of sensitivity, compassion, and commitment to each other. We must recover all the symbols of our African past and join them, as tools of equal importance, to our European symbols; keeping in mind always that neither Africa nor Europe is culturally monolithic, we must vigorously resist any return to cultural imperialism. Symbols of supremacy and inferiority must be abandoned in favour of those of equality. Perhaps we all need to see ourselves as Junkanoos, all in one nationgroup together, where every cowbell, every horn, every goatskin drum, every whistle, every shout, every prancing, gyrating, contorted enraptured soul maintains uniqueness, but still contributes equally to the ecstasy of our collective dance. We must cultivate a language that embraces diversity and celebrates difference-a language that is inclusive. And above all, we must dismantle the "purity" of whiteness. Of course, this is a monumental task, because this concept has tainted every aspect of our lives: history, geography, economics, religion, literature, psychology, all of it. Klonaris (2006) terms this "...the omnipresent nature of whiteness in the structure of our lives” (p. 4).

In an excerpt titled "The Blaze" from his novel, The Hindered Hand, Sutton E. Griggs (1905) writes about the lynching of a husband and wife, Bud and Foresta:

The mob decided to torture the victims before killing them and began on Foresta first. A man with a pair of scissors stepped up and cut off her hair and threw it into the crowd. There was a great scramble for bits of hair for souvenirs of the occasion. One by one her fingers were cut off and tossed into the crowd to be scrambled for. A man with a cork screw came forward, ripped Foresta's clothing to her waist, bored into her breast with the corkscrew and pulled forth the live quivering flesh. Poor Bud her helpless husband closed his eyes and turned away his head to avoid the terrible sight. Men gathered about him and forced his eyelids open so that he could see all. ... After three full hours had been spent in torturing the two, the spokesman announced that they were ready for the final act. The brother of Sidney Fletcher was called for and was given a match. He stood near his mutilated victims until the photographer present could take a picture of the scene ... the match was applied and the flames leaped up eagerly and encircled the writhing forms of Bud and Foresta (p. 166).

Whiteness cannot have such a grotesque legacy among people of African descent and continue to be depicted in our national narratives as pure. It is the paramount obstacle on the road to social cohesiveness, towards One Bahamas. As an artist, Herman Melville (1851) knew well what a colorcoded world we live in, and how that code influences our life together. In his metaphysical nineteenth-century novel, Moby Dick, he represents whiteness as evil in the malevolent Great White Whale. If the slave system in its inception employed cronies to create bad science, extolling the purity of whiteness, in order to give slavery legitimacy and longevity, in this age of freedom we must engage all our resources to obliterate every semblance of this foulness. As dismembered and wounded Ahab dedicated himself to searching every obscure parcel of the seascape to find and annihilate the white whale, this nation, if it ever intends to achieve 
the ideal of "One People United in Love and Service," (part of the Bahamas Pledge of Allegiance) must diligently search every nook and cranny of its collective landscape to neutralize white purity wherever it lurks, regardless of what name it embraces: white supremacy, white privilege, or ontological whiteness; always with harpoon in hand and a strident, collective shout: "Hast seen the white whale?” (p. 401).

\section{REFERENCES}

Baxter, C. (1994). Dysfunctional narratives, or mistakes were made. Ploughshares, 20(2/3).

Retrieved from http://www.pshares.org/issues/article.cfm?prm articleid=3691.

Bethel, N. (2007, June 23). On images of savages, part 2. The Nassau Guardian. Retrieved from http://nicobethel.net/blogworld/2007/06/21/onimages-of-savages-part-two/

Farrow, A., Lang, J., \& Frank, J. (2005). Complicity: How the North promoted, prolonged, and profited from slavery. New York: Ballantine Books.

Gay, S. (2006, January 16). Former MP says majority rule turned tables on discrimination. Bahama Journal. Retrieved from www.jonesbahamas.com/pdf.php?a=7004
Griggs, S. E. (1905). The blaze. In A. P. Davis \& S. Redding (Eds.), Cavalcade: Negro American writing from 1760 to present (pp. 164-167). Boston: Houghton Mifflin.

Jefferson, T. (1997). Notes on the state of Virginia. In E. C. Eze (Ed.), Race and the Enlightenment: A reader (pp. 95-103). Cambridge, MA: Blackwell.

Klonaris, H. (2006, January 28). On whiteness and being Bahamian. The Tribune, p. 4.

Lorde, A. (1984). Sister outsider: Essays and speeches. Trumansburg, NY: Crossing Press.

Melville, H. (1967). Moby Dick. New York: Bantam Books.

Morrison, T. (1987). Beloved. New York: Alfred A. Knopf.

Moss, F. (2005, December 13). Who's really playing the race card? The Tribune, p. 4.

Wilson, A. N. (1993). The falsification of Afrikan consciousness. New York: Afrikan World InfoSystem. 